\title{
Refusal for religious reasons of a blood transfusion for her husband by wife as legal proxy ignored by the doctors - can the wife claim damages?
}

\author{
D J McQuoid-Mason, BComm, LLB, LLM, PhD \\ Centre for Socio-Legal Studies, University of KwaZulu-Natal, Durban, South Africa
}

Corresponding author: D J McQuoid-Mason (mcquoidm@ukzn.ac.za)

\begin{abstract}
A scenario is presented in which a wife's request for religious reasons, and in accordance with her husband's wishes, that her husband not be given a potentially life-saving blood transfusion was ignored by the doctors. Her husband subsequently died. The question then arose whether her husband's estate, or she as his legal proxy, could bring an action for pain and suffering and sentimental damages against the doctors on behalf of her husband. When a patient dies and medical malpractice is involved, the patient's legal rights are extinguished, and their estate cannot begin or continue with a legal action for pain and suffering or sentimental damages - unless the pleadings in the case have been closed (litis contestatio). The result is that the estate or the spouse of a deceased patient may not sue for pain and suffering or sentimental damages on behalf of such patient. The spouse may only claim damages for pain and suffering and sentimental damages if he or she can show that the defendants' conduct regarding the deceased directly affected the spouse concerned. Where emotional shock was caused negligently, a spouse may only recover patrimonial damages and damages for pain and suffering. Where such shock was caused by intentional conduct, additional sentimental damages may also be claimed.
\end{abstract}

S Afr Med J 2021;111(12):1172-1173. https://doi.org/10.7196/SAMJ.2021.v111i12.16148

The question has arisen concerning whether a wife acting as her husband's legal proxy can sue doctors for damages if they ignore her and her unconscious and subsequently deceased husband's request not to be given a blood transfusion for religious reasons. The situation is illustrated by a scenario based on an actual case brought to my attention. A wife, legally authorised in terms of the National Health $\operatorname{Act}^{[1]}$ (section 7(1)(c)), specifically instructs the doctors not to give her unconscious husband - who subsequently dies - a blood transfusion because of his religious beliefs. When she receives the statement from the hospital, she notices that it includes a bill for the cost of blood used in a transfusion. As a result of her fears of how the transfusion will affect her husband's 'after life' and a feeling that she has let him down, she suffers severe mental harm, becomes depressed and requires the services of a psychiatrist. She wishes to know if she can recover damages against the doctors and report them to the Health Professions Council of South Africa (HPCSA).

In order to answer this question, it is necessary to consider: (i) the Constitution; ${ }^{[2]}$ (ii) the National Health Act; ${ }^{[1]}$ (iii) the common law; ${ }^{[3]}$ and (iv) the HPCSA Ethical Guidelines. ${ }^{[4]}$

\section{The Constitution}

The Constitution ${ }^{[2]}$ provides that everyone is entitled to bodily and psychological integrity (section 12(2)). However, in terms of the common law, ${ }^{[5]}$ when a person dies their legal rights to claim pain and suffering and sentimental damages die with them (see below). As the Constitution does not provide otherwise, a deceased person's rights to claim sentimental damages or pain and suffering for violation of their personality rights under the Constitution end when they die. Therefore, in the scenario described, the deceased's estate would not have an action for such damages resulting from a breach of his constitutional rights to freedom of religion and bodily and psychological integrity.

\section{The National Health Act}

The National Health Act ${ }^{[1]}$ requires the Minister of Health to implement the provisions of the Constitution progressively and within available resources (section 3), in accordance with the objectives of the Act (section 2(c)). The Act requires patients to give an informed consent (section $7(1)$ ), and provides a list of proxies who can act on their behalf when they become incompetent, the first being a spouse $(7(1)(b))$. Such proxies are included in the definition of 'user' (section 1(b)), and their decisions must be respected. In this instance, the unconscious patient's wife was empowered by law to consent or refuse to consent on his behalf. She qualified as a 'user' in terms of the Act, and her refusal of a blood transfusion on behalf of her husband should have been respected. Accordingly, the doctors' actions in providing her husband with a blood transfusion against her consent amount to a breach of the statutory duty imposed by the National Health Act, resulting in an unlawful act.

\section{The common law}

As mentioned, the common law provides that when a person dies their legal right to claim sentimental damages or damages for pain and suffering dies with them and their right to such claims does not accrue to their estate - unless the pleadings in the court case have already closed (litis contestatio). ${ }^{[5]}$ Furthermore, a person's spouse or family may not sue on their behalf once he or she is deceased unless the act or omission directly affects such spouse or family members (e.g. casts aspersions on their character, directly invades their privacy, or causes them to suffer emotional shock that results in treatment by a psychiatrist or psychologist). ${ }^{[5]}$ In the case described, the deceased husband was unaware of what had transpired, and had not brought a court case for sentimental damages and pain and suffering. Therefore, his estate could not bring an action on his behalf. His wife, however, could bring an action on behalf of herself as she was directly affected 
by the breach of the National Health Act, and suffered emotional shock requiring psychiatric treatment as a result. ${ }^{[6]}$

In order to succeed in a claim under the law of delict, a person must prove that the wrongful, negligent or intentional act or omission caused them to suffer damages. There is no liability for 'negligence in the air' without anyone suffering damages. ${ }^{[7]}$ A breach of a statutory duty may be used as evidence of wrongfulness in a delictual action. ${ }^{[6]}$ If the conduct was negligent, the plaintiff may only claim patrimonial damages or actual financial loss (e.g. actual medical expenses, future medical expenses, lost wages, and pain and suffering in the case of physical injuries or emotional shock). ${ }^{[8]}$ If the conduct was intentional, the plaintiff can claim patrimonial loss, and additional sentimental damages for hurt feelings or other violations of their personality rights. In the scenario described, if the blood transfusion was given as a result of negligence, the wife would be entitled to sue the doctors for the pain and suffering she experienced from the emotional shock caused by the violation of her and her husband's religious beliefs and the cost of consulting a psychiatrist. ${ }^{[8]}$ If the doctors intentionally ignored her instructions, she could, in addition, claim sentimental damages for her hurt feelings ${ }^{[9]}$ resulting from their religious beliefs being ignored.

With regard to the claim for the cost of the blood transfusion, the court could decide that on the basis of the law of contract, the wife had not contractually agreed to such a procedure or to pay the costs involved. ${ }^{[10]}$ Such a decision was made where hospital staff had failed to raise the side of a bed containing an elderly female patient who fell out and injured herself. The hospital tried to charge the son of the patient, who had undertaken to pay the costs of treatment for his mother's original complaint, with the additional costs incurred through the negligence of the hospital staff. The court held that the son had not contractually agreed to pay the additional costs resulting from her injuries and could not be held liable for them. ${ }^{[10]}$

\section{The HPCSA Ethical Guidelines}

The HPCSA Ethical Guidelines ${ }^{[4]}$ deal specifically with informed consent and echo the provisions of the National Health Act (section 7(1)) and the common law. ${ }^{[11]}$ In terms of the Guidelines, it would be unethical for practitioners to treat patients without their consent or the consent of their legal proxies - except in emergencies, provided that it is not against the previously expressed wishes of the patients or their legal proxies, or if the medical condition of the patient is a serious threat to public health. ${ }^{[12]}$ In the scenario described, the legal proxy had clearly stated that she and her husband refused to consent to a blood transfusion. This was ignored by the doctors - even if they did it to try to save the deceased's life, it was against the religious beliefs and wishes of the deceased and the proxy, which rendered their conduct unethical and illegal. The doctors could be reported to the HPCSA by the widow, and it is likely that they would be subjected to a disciplinary hearing and found guilty of unprofessional conduct. ${ }^{[4]}$

\section{Conclusions}

When a patient dies and medical malpractice is involved, the patient's legal right to begin or continue with a legal action for pain and suffering or sentimental damages is extinguished - unless the pleadings in the case have been closed (litis contestatio). The result is that the estate or the spouse of a deceased patient may not sue for pain and suffering or sentimental damages on behalf of such patient. The spouse may only claim damages for pain and suffering and sentimental damages if he or she can show that the defendants' conduct regarding the deceased directly affected such spouse. Where emotional shock was caused negligently, a spouse may only recover patrimonial damages and damages for pain and suffering. Where such shock was caused by intentional conduct, additional sentimental damages may also be claimed.

Declaration. None.

Acknowledgements. None.

Author contributions. Sole author.

Funding. National Research Foundation.

Conflicts of interest. None.

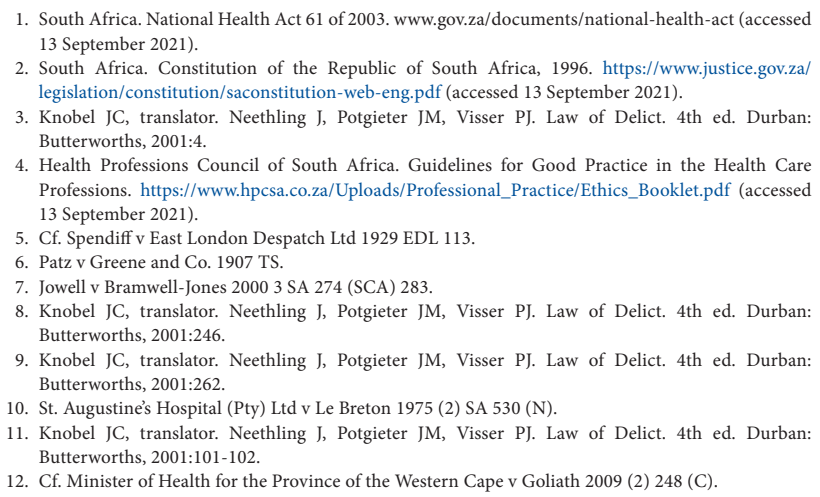

Accepted 3 October 2021. 